\title{
A soft technology to improve survival and reproductive performance of Litopenaeus stylirostris by counterbalancing physiological disturbances associated with handling stress
}

\author{
Nelly Wabete ${ }^{\underline{a}, \underline{b}}$, Liet Chim ${ }^{\underline{a}}$, Dominique Pham ${ }^{\underline{a}}$, Pierrette Lemaire ${ }^{\underline{a}}$ and Jean-Charles Massabuau ${ }^{\underline{b}}$ \\ aIFREMER, Département d'Aquaculture en Calédonie, B.P. 2059, 98846 Nouméa, New Caledonia \\ ${ }^{b}$ Laboratoire d'Ecophysiologie et d'Ecotoxicologie des Systèmes Aquatiques, UMR 5805. Université Bordeaux 1 \\ and CNRS, Place du Dr B. Peyneau, 33120 Arcachon, France
}

Corresponding author : liet.chim@ifremer.fr

\begin{abstract}
The consequences of handling stress (fishing, transfer, eyestalk ablation) on shrimp broodstock are poorly documented. The weakness of farmed shrimp, Litopenaeus stylirostris, during winter is a major problem in New Caledonia, because of seasonal climate (tropical-sub-temperate). The transfer of broodstock in winter from earthen outdoor ponds to indoor maturation tanks in the hatchery $\left(T=20^{\circ} \mathrm{C}\right.$, Salinity $=35 \%$, fed shrimp) usually leads, after $48 \mathrm{~h}$, to high mortality (up to $70 \%)$. Eyestalk ablation to induce ovarian maturation in females leads to further mortality.
\end{abstract}

Starting from a background analysis of physiological disturbances (initial osmoregulatory imbalance) associated with handling stress (Wabete, N., Chim, L., Lemaire, P., Massabuau, J.-C., 2004.

Caractérisation de problèmes de physiologie respiratoire et d'échanges ioniques associés à la manipulation chez la crevette pénéide Litopenaeus stylirostris à $20^{\circ} \mathrm{C}$. Styli 2003. Trente ans de crevetticulture en Nouvelle-Calédonie. Ed. Ifremer. Actes Colloq. 38, 75-84.), we developed a protocol using a soft technology, based on modifications of water salinity, temperature and feeding regime. The aim was to minimize problems of osmoregulatory imbalance and associated mortalities. The protocol we developed, called the LSD OT protocol (Low Salinity and Diet, Optimal Temperature), was first evaluated on sub-adult shrimp (20-25 g) and then applied to broodstock. Survival after transfer and following eyestalk ablation, as well as reproductive achievement (spawning rate, nauplii number) was considerably improved when shrimps were transferred under "physiological comfort" i.e. warmed isosmotic water $\left(26^{\circ} \mathrm{C}\right.$ and $26 \%$ ) and unfed for $3 \mathrm{~d}$. This new handling protocol, based on a better control of salinity, temperature and feeding conditions, has been transferred successfully to private hatcheries and already contributes to an increased profitability of New-Caledonian shrimp industry

Keywords: Shrimp; Litopenaeus stylirostris; Broodstock; Handling stress; Spawning; Eyestalk ablation 


\section{Introduction}

In 2004, New Caledonia produced 2,200 tonnes of top quality farmed shrimps. The whole caledonian production is based on a single species, Litopenaeus stylirostris, endemic to the Pacific coasts of Central and South America (from Mexico to northern Peru) (PérezFarfante and Kensley, 1997). The control of the complete life cycle (AQUACOP, 1979) and the development of specific rearing techniques (AQUACOP, 1983; Galinié, 1989) have allowed this introduced species' commercial farming since 1980.

After being reared in earthen ponds, broodstock are harvested and transferred to the hatchery where they are conditioned for reproduction (Galinié, 1989). The handling during transfer and eyestalk ablation of the females cause a high mortality rate, observed in all the hatcheries both in cold and hot seasons. Consequently, 20,000 broodstock shrimps (males and females) must be reared to obtain the 200 million post-larvae necessary to stock in the growout ponds.

Eyestalk ablation is carried out a few days after the shrimps' stocking into the hatchery, to induce ovarian maturation and spawning (Chamberlain and Lawrence, 1981; Ottogali et al., 1988). Each eyestalk contains a neuroendocrine complex that synthesises and secretes the Gonado Inhibiting Hormone (GIH) (Charniaux-Cotton, 1985). The removal of one source of GIH is sufficient to prevent the inhibition of vitellogenesis and trigger ovarian maturation. This ablation is obviously a stressful factor which affects many aspects of the animal's physiology including the immune system (Perazzolo et al., 2002) and can alter the survival of the broodstock (Browdy, 1992). In the shrimp Penaeus notialis, Rosas et al. (1993) reported that the stress caused by unilateral eyestalk ablation led to an increase in ventilatory activity and a decrease in oxidative metabolism.

The metabolic and physiological effects of the handling of crustaceans have been less studied. In L. stylirostris, osmotic homeostasis approximately equals 810 mos M.kg ${ }^{-1}$ when water temperatures are between 20 and $28{ }^{\circ} \mathrm{C}$. Handling stress of the animal during transfer into a hatchery leads to disturbances in osmoregulation and oxygen transport from the gills to the tissues. In particular, a decrease in oxygen affinity of hemocyanin caused by an increase in osmotic blood pressure has been demonstrated, whereas partial oxygen pressure in the arterial blood remains stable. It has also been shown that shrimp transferred at $25-28{ }^{\circ} \mathrm{C}$ requires $24 \mathrm{~h}$ to recover its osmoregulatory capacity (OC), while in winter, at $22{ }^{\circ} \mathrm{C}$, recovery time can be as long as 5 to 7 days (Wabete et al., 2004). These disturbances are associated with problems of oxygen supply which weaken the animals and could ultimately result in a heart attack. A similar result has been described in the case of acid rain toxicity mechanisms and hydromineral disturbances induced in fish (Wood, 1989).

In this study, based on our analysis of ionoregulation problems caused by the handling of $\underline{L}$. stylirostris (Wabete et al., 2004), we have perfected a protocol using a "soft" technology which could reduce the results of handling stress and the associated mortality. Our approach was based on adjustments to salinity, temperature and feeding regime. The protocol was tested in New Caledonia on sub-adult shrimps and broodstock in experimental and commercial hatcheries. The transfer conditions were evaluated according to the survival and the reproductive achievement of the broodstock: maturation of the females, fecundity and number of nauplii per spawn. As the problems associated with handling began with an imbalance in the ion exchange system, the idea was: (i) to manipulate water salinity in order to limit ion and water exchanges and the associated variations in blood $\mathrm{pH}$ (Truchot, 1987); (ii) to promote the functioning of ion exchange systems by returning to the optimal temperature for the species; (iii) to avoid feeding shrimps in order to limit oxygen requirements, to minimize use of gas transport system and transbranchial ion exchanges which ensure the acid-base regulation in the blood during post-prandial period (Legeay and 
Massabuau, 1999; 2000). The final protocol will be termed LSD OT for Low Salt and Diet, Optimal Temperature.

\section{Materials and methods}

\subsection{Facilities and material}

The maturation tanks were circular in shape and made in Scobalite ${ }^{\circledR}$ (fibreglass sheet 1 mm thick). Two sizes of tank were used: 4 metre diameter tanks for females and 3 metre diameter tanks for males. All the tanks were $1.25 \mathrm{~m}$ high and held $50 \mathrm{~cm}$ of water. The bottom of the tanks was covered by a lower layer of gravel separated by Bidim ${ }^{\circledR}$ (geotextile) from an upper layer of sand. The total thickness of the substrate was 8-10 cm. Each tank was supplied with sea water through a PVC tube (4 cm diameter) with a shutter. A PVC tube drain ( $9 \mathrm{~cm}$ diameter) fixed vertically in the centre of each tank determined the water's height. Water renewal was continuous, at a rate of $50 \%$ per day for females and $100 \%$ for males. Each tank was also equipped with an air-lift system connected to a circular network of PVC tubes buried in the lower sediment layer. With this system, the water circulated from top to bottom through the sand base which thus acts as a mechanical filter. Additional aeration was provided at the bottom of each tank by two high pressure air diffusers.

\subsection{The shrimps}

\subsubsection{Rearing}

For the elaboration of the new transfer protocol, the experiments on Litopenaeus stylirostris were carried out in two steps (i) firstly on sub-adult shrimps (average weight 20-25 g.) and then on broodstock (45 to $75 \mathrm{~g}$ ). The sub-adults shrimps were reared in earthen ponds $\left(1,000 \mathrm{~m}^{2}\right)$ for four months, starting with 20-day post-larvae (P20) at density of 20 animals per $\mathrm{m}^{2}$. The rearing process of broodstock's production (Ottogalli et al., 1988) included two stages: (i) from the post-larval stage to an average weight of $20 \mathrm{~g}$, the animals were reared at a density of $1-2$ animals. $\mathrm{m}^{-2}$ for 4 months, (ii) the $20 \mathrm{~g}$ shrimps were then transferred into another pond for a further 4 months at a lower density $\left(0.5\right.$ per $\left.\mathrm{m}^{2}\right)$ while they reached their reproduction size (40 to $60 \mathrm{~g}$ ).

During rearing period in ponds, animals were fed twice a day on commercial feed pellets. A fresh food supplement (chopped squid) was given once a week, during the second stage of broodstock's production.

\subsubsection{Capture and transfer of the broodstock}

At the end of the rearing period, the broodstock in the earthen ponds were caught with a cast net and transferred to 50-litre containers filled with seawater (10 animals / container). The oxygen in the transport water was maintained at saturation point with compressed air aerator powered by the tractor battery. In the hatchery, the animals were sorted by hand, according to sex, into the maturation tanks. As the water in these tanks came from the lagoon, it was at a temperature of about $21^{\circ} \mathrm{C}$ in winter and $28^{\circ} \mathrm{C}$ in summer.

In winter after the eyestalk ablation, the water temperature in the female tanks was gradually increased to reach $29^{\circ} \mathrm{C}$ by 1 to $2^{\circ} \mathrm{C}$ a day with a heater (2,000 watts). The water in the male tanks was not thermo regulated.

As soon as they were transferred into the maturation tanks, the animals were fed twice a day (8am and 4pm) with fresh food (mussel, squid at $9 \%$ of shrimps biomass) and once a day $(1 \mathrm{pm})$ with a special commercial feed pellet (at $3 \%$ of shrimp biomass). The daily diet is adjusted on leftovers from the previous day

In the maturation room, the photoperiod (day/night: $14 \mathrm{~h} / 10 \mathrm{~h}$ ) was set from the first day: the spotlights above the tanks were switched on at $7 \mathrm{pm}$ and turned off at 9am. In the 
natural environment, spawning takes place at night, so adjustment of photoperiod permits the observation of spawning at the beginning of the afternoon.

\subsubsection{Maturation, insemination, spawning and determining the number of nauplii per spawn.}

Four days after the animals were transferred to the hatchery, the females were fished out individually with a landing net to undergo unilateral eyestalk ablation (Ottogalli et al., 1988). To prevent haemorrhage, a wire ligature was used below the section. Once the operation was over, the animals were put back in their initial tank where in winter the water was then increased to $29^{\circ} \mathrm{C}$. This temperature was maintained throughout the production period (2 to 3 weeks). Eyestalk ablation triggers ovarian maturation and leads the shrimps to spawn.

Depending on the season, the first females ready to spawn were observed two to four days after eyestalk ablation. They are noticeable by their developed ovaries, orange/brown in colour, which are easily visible through the carapace along the dorsal part of the abdomen from the cephalothorax to the base of the telson. The state of gonad development was assessed every day by directing a light towards the animal in its tank. The mature females spawned between $11 \mathrm{am}$ and $2 \mathrm{pm}$.

In Litopenaeus stylirostris, mating occurs a few hours before spawning. In the laboratory, the males and females were kept in separate tanks, and the females that were ready to spawn were inseminated manually one to two hours before spawning occurred. The spermatophores were extracted by a simple dorso-ventral pressure on the $5^{\text {th }}$ pair of pereiopods on the male. The sperm was then extracted from the spermatophore and spread, using forceps, on the thelycum (simple depression of the cuticule in the ventral area of the female) between the two last pair of pereiopods. The inseminated females were then placed individually in calm (without aeration) and dark spawning tanks. A few hours after spawning, the females were transferred back to their original tanks.

\subsection{Experimental protocols}

\subsubsection{Determination of the broodstock isosmotic point.}

Experiments were carried out in January and April 2004. Shrimps were caught from an earthen pond ( $\mathrm{T}=26.8{ }^{\circ} \mathrm{C} ; \mathrm{S}=36 \%$ ) and 6 to 7 animals were stocked in each 10 circular polyester tanks (1.20 diameter and $0.65 \mathrm{~m}$ high, capacity $500 \mathrm{l}$ ). The tanks had been previously filled with filtered seawater (35\%). The water temperature throughout the experiment was $26.7 \pm 0.4{ }^{\circ} \mathrm{C}$ (mean \pm 1 standard error). Females weighted $45.5 \pm 0.7 \mathrm{~g}(\mathrm{n}=36)$ and males, $36.4 \pm 0.4 \mathrm{~g}(\mathrm{n}=32)$.

Three days after transfer, water salinity was gradually reduced ( 5 ppt /day) by addition of fresh water to obtain a range of 5 salinities (35, 30, 25, 20 and 15\%o), with 2 tanks per salinity. The animals were kept unfed in these different environments for 24 hours before blood was sampled. Osmotic pressures were measured only on animals at the intermoult stage (stages C and D0; Drach and Tchernigovtzeff, 1967).

\subsubsection{Experimental transfer of sub-adults ( 15 to $35 \mathrm{~g}$ )}

Two preliminary experiments were carried out with sub-adult animals weighing 15 to 35 g in June 2003 (winter) and October 2003 (winter-summer transition period).

For the winter experimental transfer, 400 sub-adults weighting $22.1 \pm 0.2 \mathrm{~g}$ were transferred from the rearing pond into the hatchery at day $0\left(\mathrm{~d}_{0}\right)$ and distributed in batches of 100 shrimps into 4 maturation tanks. A specific treatment was applied to each tank: Control [35;21;F] (Salinity $35 \%$ o, ambient temperature $21^{\circ} \mathrm{C}, \mathrm{F}=$ feeding); [26;21;F] (Salinity 26\%o, temperature $21^{\circ} \mathrm{C}$, feeding); [26;26;F] (Salinity 26\%, $\mathrm{T}=26{ }^{\circ} \mathrm{C}$, feeding) and [26;26;UF], called the LSD OT protocol or Low Salt and Diet, Optimal Temperature (Salinity 26\%o, T = 
$26^{\circ} \mathrm{C}$, UF = unfed). The $26 \%$ salinity corresponds to the isosmotic point of sub-adult animals (Lemaire et al., 2002). In the first 3 treatments, the animals were fed a single food ration per day, $4 \%$ of the biomass, with commercial feed pellets divided into two meals (8am and 4pm). Mortalities were recorded twice a day (8am and $4 \mathrm{pm})$ for 4 days after transfer $\left(\mathrm{d}_{0}\right.$ to $\left.\mathrm{d}_{4}\right)$.

Based on the results of the previous experiment, we then tested the effect of the low salinity and diet (LSD) protocol on the consequences of eyestalk ablation in sub-adult females. The experiments were carried out in October 2003. Seventy-four females, average weight $=26.4 \pm 0.3 \mathrm{~g}$, were fished at day $0\left(\mathrm{~d}_{0}\right)$ and sorted into 2 maturation tanks: one control tank (Salinity 35\%o, ambient temperature, food) and one experimental tank for the LSD condition (Salinity 26\%o, ambient temperature, no food). The average ambient temperature of tanks' water until $\mathrm{d}_{5}$ was $24.8 \pm 1.3^{\circ} \mathrm{C}$. Eyestalk ablation was practised at $\mathrm{d}_{3}$. The LSD protocol was applied during 5 days $\left(d_{0}\right.$ to $\left.d_{4}\right)$. At $d_{5}$, two days after eyestalk ablation of females, feeding was resumed and tanks' water was heated to reach $28.5 \pm 0.5{ }^{\circ} \mathrm{C}$ two days after $\left(d_{7}\right)$. At $d_{6}$, salinity was gradually increased to reach $35 \%$ at $d_{8}$. Mortality was monitored for 11 days $\left(\mathrm{d}_{0}\right.$ to $\left.\mathrm{d}_{11}\right)$ after transfer.

\subsubsection{Experimental transfers of the broodstock (45 to $75 \mathrm{~g}$ )}

In September 2003 (winter), the LSD OT protocol was tested on broodstock survival after their transfer indoors. Then, 188 females $(\mathrm{Pm}=68.0 \pm 1.2 \mathrm{~g})$ and 184 males $(\mathrm{Pm}=51.9$ $\pm 0.6 \mathrm{~g}$ ) were harvested from earthen pond (salinity $=35 \%$, temperature $=21^{\circ} \mathrm{C}$ ), sorted by sex and transported in tanks containing pond water $\left(35 \%\right.$; $\left.21^{\circ} \mathrm{C}\right)$ to maturation room. Fifteen minutes after harvesting, shrimps were stocked in 6 maturation tanks ( $\mathrm{n}=60-65 / \operatorname{tank}$ ): 3 (diameter $=3 \mathrm{~m}$ ) for males and 3 (diameter $=4 \mathrm{~m}$ ) for females. One tank of males and one tank of females were used as controls (salinity and temperature identical to initial pond conditions). The LSD OT protocol was applied to the other four tanks from $d_{0}$ to $d_{3}$ with salinity gradually increased from 26 to $35 \%$ ofter $d_{4}$. On the fifth day $\left(d_{5}\right)$, the animals were fed and the water in the females' tanks was heated to $28.1 \pm 0.7^{\circ} \mathrm{C}$ at $\mathrm{d}_{8}$ when the females underwent eyestalk ablation. After fishing, the blood osmolality of the unfed shrimps in intermoult stage was measured at 15 min (just before repartition in maturation tanks), $4 \mathrm{~h}$ after stocking and then, every $24 \mathrm{~h}$ until $120 \mathrm{~h}\left(\mathrm{~d}_{5}\right)$.

In July 2004, the experiment was repeated to check the reproducibility of our technology during broodstock transfer, and to test the LSD OT protocol on survival rate after eyestalk ablation and on reproduction achievement of females. This experiment was carried out on 300 females, average weight $51.9 \pm 0.4 \mathrm{~g}$, in 4 tanks ( $4 \mathrm{~m}$ diameter, density $5 / \mathrm{m}^{2}$ ) and 268 males (average weight $41.9 \pm 0.3 \mathrm{~g}$ ) in 4 tanks ( 3 m diameter, density $8.5 / \mathrm{m}^{2}$ ). The LSD OT protocol was applied from $\mathrm{d}_{0}$ to $\mathrm{d}_{4}$ (2 tanks per sex) with a gradual increase in salinity from 26 to 35\% from $d_{5}$. After eyestalk ablation (practised on $d_{4}$ ), the water in the female tanks was heated to $28{ }^{\circ} \mathrm{C}$. Then, the females ready to spawn were monitored for each treatment. After artificial insemination of the mature females, the spawn was collected, the number of eggs and nauplii per female were determined. Moreover, the number of dead shrimps was recorded twice a day (8am and 4pm) until $144 \mathrm{~h}\left(\mathrm{~d}_{6}\right)$.

\subsubsection{Analysis}

Determination of moult stage. Molting stages were determined by microscopical examination of antennal scales according to the method of Drach and Tchernigovtzeff (1967).

Haemolymph sampling. Blood was sampled $(50 \mu \mathrm{l})$ using a glass capillary with a hypodermic needle introduced into the cardiac cavity. The arterial blood then rise spontaneously in spurts into the capillary, and observation of these beats certifies arterial origin (Forgue et al., 1992; Massabuau and Forgue, 1996). 
Osmotic pressure. The measuring device used was a Wescor ${ }^{\circledR}$, model 5520, osmometer with a $10 \mu \mathrm{l}$ sample on a $6.35 \mathrm{~mm}$ diameter filter paper. The blood and the tank water osmolality were expressed in mosM. $\mathrm{kg}^{-1}$. Lemaire et al. (2002) had previously determined the linear function linking salinity expressed in ppt and in mosM.kg- ${ }^{-1}$. This function is described in the following equation:

$$
\mathrm{y}=28.939 \mathrm{x}-23.103
$$

where $\mathrm{x}$ and $\mathrm{y}$ are the salinity expressed in ppt and in mosM.kg-1, respectively.

Monitoring the spawning - After eyestalk ablation and until the end of the experiment, the females that were ready to spawn were monitored and systematically inseminated before being placed individually into the spawning tanks. Cumulative spawning (CS in \%) can be calculated using the following formula :

$$
\mathrm{CS}=\left(\sum_{\mathrm{i}=0}^{\mathrm{n}} \mathrm{Pi} / \mathrm{Fi}\right) * 100 \text {, }
$$

where $\mathrm{i}=$ day $\mathrm{i} ; \mathrm{Fi}=$ number of females on day $\mathrm{i}$; $\mathrm{Pi}=$ number of spawns on day $\mathrm{i}$.

The daily average spawning (DS in \%) can be calculated using the following formula:

$$
\mathrm{DS}=\mathrm{CS} / \mathrm{d}_{\mathrm{n}} \text {, }
$$

where $d_{n}=$ number of days since eyestalk ablation.

Number of nauplii per spawn. The day after spawning, the number of nauplii was determined for each spawn. Each spawn was collected, by draining the spawning tank over a $100 \mu \mathrm{m}$ filter, and then poured in a 10-litre bucket. After manual mixing, a volumetric count of the nauplii was done from 2 samples of $1 \mathrm{ml}$ each.

Determination of spawning rank. After spawning, the females were tagged and returned to their maturation tank. Tagging was carried out by injecting coloured elastomer (Northwest Marine Technology) under the cuticle of the abdomen; the number and rank of spawns for each female could thus be determined.

\subsection{Production results at the hatcheries.}

The application of the LSD OT protocol to a large scale production was studied by a statistical analysis of the data from Saint-Vincent experimental hatchery (Ifremer) and from a commercial hatchery in northern New Caledonia, "Ecloserie du Nord" (EDN), (BP 16, 98860 - Koné). This study was carried out in Saint-Vincent hatchery on 87 production batches of broodstock in standard conditions (summer, $n=45$; winter, $n=42$ ) and on 24 production batches ( $\mathrm{n}=12$ for each season) using the new protocol. For the commercial hatchery, data from 21 batches were analysed, between 2001 and 2004, before and after the application of LSD OT protocol. The first 14 batches (2001 to 2003), managed according to standard procedure, were made of 8 summer productions and 6 winter productions. The last seven batches (2003 and 2004, 4 during summer and 3 during winter) were carried out with broodstock transferred according to the LSD OT protocol.

The experimental Saint-Vincent hatchery does not produce post-larvae for sale. The shrimps are produced solely for genetic or experimental research (physiology, nutrition and pathology studies). For our experiments, all the mature females were inseminated and allow to spawn, regardless of the requirements for larval rearing .

\subsection{Statistical analyses}

The data are presented in individual values, frequency histograms and/or average values \pm 1 standard error (SE). Statistical analysis of the data was carried out using StatView ${ }^{\circledR}$ V5 software (SAS Institute Inc.). Survival rates were compared according to treatment using the $\chi^{2}$ test. Osmotic pressure and reproduction performance indexes were subjected to one-way 
analysis of variance (ANOVA) or Student test. A square root Arcsin transformation was used before processing percentage data. A significant difference was admitted for $\mathrm{p}<0.05$.

\section{Results}

\subsection{Iso-osmotic point of the broodstock shrimps}

Variations in blood osmotic pressure (OP) according to tank water OP are presented in figure 1 . Since no difference was observed regarding the sex of the animals, all data are pooled. The hyper-hyporegulation polynomial curve $\left(y=-1.32 x^{2}+0.4 x+529\right)$ intersects the iso-osmolality line at the isosmotic point of 756 mosM.kg-1 (salinity of $26.9 \%$ ). Below this point, broodstock shrimp hyper-regulates its blood osmolality and above this value, animal hypo-regulates.

\subsection{Influence of water quality on mortality caused by the transfer into hatchery}

Sub-adult shrimps. After capture from earthen pond (salinity 35\%; temperature $21^{\circ} \mathrm{C}$ ) and transfer into indoor tanks, the evolution of mortality rates was function of physicochemical conditions in tanks (Fig. 2). In the control batch subjected to the usual technique [35\% ; $21{ }^{\circ} \mathrm{C}$; Fed] (Fig. 2A), mortalities appeared 48-72 $\mathrm{h}$ after transfer, with a peak at 48 (13\%) and $54 \mathrm{~h}(18 \%)$. This mortality at $48-54 \mathrm{~h}$ was reduced to 12 and $2 \%$ by a decrease of water salinity to 26\%o (near isosmotic point) (Fig. 2B) and to 7 and $2 \%$ if tank's water was also heated (Fig. 2C). Finally the best results were obtained when shrimps are transferred into isotonic water at $26{ }^{\circ} \mathrm{C}$ and kept unfed ([26;26;UF], LSD OT protocol) since mortality at $48 \mathrm{~h}$ was reduced to $1 \%$ (Fig. 2D). The survival $96 \mathrm{~h}$ after transfer appeared to be clearly dependent on the number of favourable parameters and was significantly improved $\left(\chi^{2}\right.$ test; $\mathrm{p}<0.01)$ in the 3 treatments $([26 ; 21 ; \mathrm{F}]=77 \%$; $[26 ; 26 ; \mathrm{F}]=82 \%$; $[26 ; 26 ; \mathrm{UF}]=96 \%)$ compared to the control (60\%, Fig. 2E).

Broodstock. To confirm the results obtained previously with sub-adult shrimps weighing 15-35 g, experiments were repeated with broodstock shrimps weighing 45 to $75 \mathrm{~g}$. The haemolymph osmolality is immediately increased after fishing, as OP measured fifteen minutes after fishing and transport in tanks containing pond water (35\%o; $21{ }^{\circ} \mathrm{C}$ ) was respectively $910.7 \pm 11.8$ and $911.0 \pm 10.7$ mosM.kg ${ }^{-1}$ for shrimps of standard and LSD OT batches (Fig. 3B). In maturation tanks, when transfer was performed into hypertonic water (standard conditions, Fig. 3A), osmolality remained high (approximately 900 mosM.kg ${ }^{-1}$, Fig. 3B) during the five days of experiment and mortality was particularly heavy with a peak at 48 h (29.8 $\pm 2.4 \%$, Fig. 3C). When shrimps were transferred in a low salinity and warmed water, the blood OP decreased rapidly to isosmotic point in the first 24 hours and increased slowly from $72 \mathrm{~h}$ with water salinity to reach OP reference value at $120 \mathrm{~h}$. The LSD OT protocol reduced considerably total mortality which was $25.6 \%$ against $54.1 \%$ in standard conditions ($52.7 \%)$.

\subsection{Effect of LSD OT protocol on survival after eyestalk ablation.}

As the previous results showed that adjustment of salinity, temperature and feeding enable the shrimps to better cope with the handling stress during fishing, the LSD OT protocol had been assessed on survival after eyestalk ablation (additional stress for broodstock). Firstly, a simplified protocol which just included "Low Salt and Diet" (LSD) condition was tested on sub-adult females; indeed, experiments were performed at the end of winter (water temperature increased to $25{ }^{\circ} \mathrm{C}$ ). Then, the LSD OT protocol had been tested during winter on broodstock.

Sub-adults. As previously, the animals transferred in standard conditions (salinity of $35.9 \pm 0.2 \%$, Fig. 4 A) suffered a greater mortality $48 \mathrm{~h}$ after fishing and transfer than in LSD 
conditions (Fig.4B). So survival at $72 \mathrm{~h}$, before eyestalk ablation, was respectively 76.9 and 88.6\% with standard and LSD protocols (Fig. 4B). After eyestalk ablation, additional mortality was observed for each batch and at the end of the experiment (at $240 \mathrm{~h}$ ), final survival was respectively 38.5 and $68.6 \%$ for the control and LSD batches. Transfer in an isotonic water therefore improved the animals' survival by $15.2 \%$ before eyestalk ablation and by $78.2 \%$ after the two stresses.

Broodstock. In the control batches, survival rates at $72 \mathrm{~h}$ were similar for females (74.3 $\pm 1.0 \%$, Fig. 5A) and males (76.9 $\pm 0.7 \%$, Fig. 5B). Unilateral eyestalk ablation carried out at $72 \mathrm{~h}$ has amplified the mortality rate on the females. Thus, survival at $144 \mathrm{~h}$ after transfer was only $19.9 \pm 4.6 \%$ for the females compared with $58.2 \pm 4.5 \%$ for the males. The application of the LSD OT protocol once again reduced mortality following the two handling stresses: (i) survival rates at $72 \mathrm{~h}$ after transfer were improved to $90.0 \pm 1.8 \%$ for females and to $88.1 \pm$ $4.5 \%$ for males in the treated batches; (ii) at $144 \mathrm{~h}$, seventy-two hours after eyestalk ablation of the females, the batches transferred in LSD OT conditions showed a survival rate of $54.7 \pm$ $2.9 \%$, compared to $19.9 \pm 4.6 \%$ for the control groups. The final survival rates of males which only underwent the stress of transfer were $78.4 \pm 2.2 \%$ in the treated batches and 58.2 $\pm 4.5 \%$ in the control treatments.

\subsection{Influence of LSD OT protocol on spawns and nauplii numbers}

Study in an experimental hatchery. After broodstock acclimation either in standard or LSD OT conditions in maturation room of the Saint-Vincent experimental hatchery (Ifremer), spawning has been monitored in September 2003 (Fig. 6A) and July 2004 (Fig. 6B). Animals treated with the LSD OT protocol spawned earlier than the control animals. The first spawns in the control and treated batches occurred at 96 and $72 \mathrm{~h}$, respectively, after eyestalk ablation in September, and at 168 and $120 \mathrm{~h}$ in July. The one day difference between September and July can be explained by experimental conditions. In September 2003, eyestalk ablation was carried out at $28{ }^{\circ} \mathrm{C}$ and $35 \%$ for the two treatments (control and LSD OT), whereas in July 2004, the ablation was performed in isotonic water at $26^{\circ} \mathrm{C}$ and afterwards salinity and temperature were gradually increased to $35 \%$ and $28^{\circ} \mathrm{C}$ ( 2 days after eyestalk ablation).

The average rates of daily cumulative spawning present a first phase of acceleration followed by a second phase with a clear slowing down (Fig. 6C and 6D). In the control animals, the acceleration phase lasted 48 hours in September (72 to $120 \mathrm{~h}$ ) and July (144 to 192h). In the LSD OT conditions, it lasted $48 \mathrm{~h}$ in September (48 to $96 \mathrm{~h}$ ) and $120 \mathrm{~h}$ in July (96 to $216 \mathrm{~h}$ ). So, the acceleration phase of cumulative spawning was therefore considerably longer for females that had been transferred and ablated according to LSD OT protocol $(+150 \%)$. At the end of this acceleration phase, the cumulative spawning rates (Fig. 6 A\&B) in September and July were respectively 20 and 38.4\% for the control and 33.3 and $71.9 \%$ for the LSD OT treatment. In September, final cumulative spawning rates (264 h after eyestalk ablation) were $60 \%$ for the control and $115 \%$ for the LSD OT treatment. At the end of the July production (456 h after eyestalk ablation), they were 131\% for the control and $190 \%$ for the LSD OT batch. Thus in both cases, the LSD OT protocol increased spawning by 55 to $60 \%$. Moreover, the observation of spawns' frequency during July production showed that some of the treated females spawned as many as 4 times, while the control animals spawned a maximum of twice (Fig. 7).

From the survival and spawning rate data obtained experimentally, the yield (total number of nauplii harvested over the production period) from a batch of 100 broodstock shrimps was estimated according to the season and the transfer protocol applied (Tab. 1). Excepted the number of nauplii per spawn, which was $20 \%$ higher in summer for the females transferred in standard conditions, the new transfer protocol produced a significant improvement for all the other rearing indicators: survival rate, spawning rate per female, total 
number of spawns and total number of nauplii. In terms of total production of nauplii, the LSD OT protocol showed an improvement of $60 \%$ and $175 \%$, in summer and winter respectively.

Data study from a professional hatchery. Figure 8 shows the evolution of survival rates before and after the LSD OT protocol application. The analysis of production results showed that the application of the LSD OT protocol in a commercial hatchery (Ecloserie du Nord, New Caledonia) has improved broodstock's survival rates in maturation rooms. Indeed four days after transfer, survival rate increased in summer, from 63.5 to $90.2 \%$ ( $=0.0007)$ and in winter, from $90.7 \%$ to $94.7 \%(\mathrm{p}=0.61)$ (Fig.8A). Survival rates 15 days after transfer -which took into account the transfer and the eyestalk ablation- were significantly enhanced from 34.5 to $77.0 \%$ in hot season $(\mathrm{p}<0.01)$ and from 66.5 to $87.3 \%$ in winter $(\mathrm{p}<0.05)$ (Fig.8B). Moreover, the application of LSD OT protocol has improved the total nauplii production by respectively 65 and $7 \%$ in summer and winter (Table 2). An ANOVA analysis of all the data shows a very significant seasonal effect $(p=0.0003)$.

\section{Discussion}

In this study, we have shown that it was possible to reduce mortalities associated with

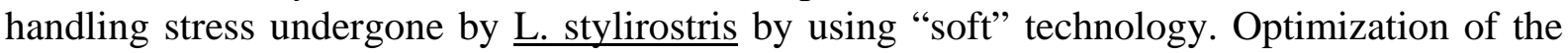
handling conditions of broodstock (Low Salt and Diet, Optimal Temperature) from the very beginning of the reproduction cycle improves their performances in the hatchery: a better survival rate combined to a higher spawning rate leads to an increase of nauplii number per cycle.

\section{Application of the LSD OT protocol and mortality decrease associated with handling stress}

The metabolic and physiological consequences of handling aquatic animals have been studied a very few times. The major problems associated with the handling of $\underline{L}$. stylirostris in summer and winter are (i) a collapse in osmoregulatory ability, (ii) a short-term stimulation of the oxidative metabolism, and (iii) an over-oxygenation of the blood (first $24 \mathrm{~h}$ ) (Wabete et al., 2004). The disturbance of osmoregulation in winter at $22{ }^{\circ} \mathrm{C}$ lasted for 4 to 5 days, whereas in summer, at $28{ }^{\circ} \mathrm{C}$, recovery occurred in less than $24 \mathrm{~h}$. In L. stylirostris (Wabete et al., 2004), as in other crustaceans, a decrease in the osmoregulatory ability leads to a drop in the affinity of haemocyanin (respiratory pigment) for oxygen (Truchot, 1987). The drop in the haemolymph's ability of transporting oxygen, consequence of the blood osmolality disturbances, implies a potential increase in heartbeat rate. At the very least, this phenomenon weakens the animal and at worst, may result in a heart attack. This is a highly possible hypothesis with $\underline{L}$. stylirostris, given its exceptional metabolic requirements, even in winter (Wabete et al., 2004).

The iso-osmotic point measured at $26{ }^{\circ} \mathrm{C}$ in L. stylirostris broodstock (756 mosM.kg ${ }^{-1}$ or $26.9 \%$ ) is higher than in the juvenile animals ( 735 mosM.kg ${ }^{-1}$ or $26.2 \%$ - Lemaire et al., 2002). The same trend is observed for the shrimp Penaeus japonicus which presents a higher isosmotic point in the adult ( 880 mosM.kg-1) compared to the post-larvae (820 mosM. $\mathrm{kg}^{-1}$ ) (Charmantier-Daurez et al., 1988).

The blood Osmotic Pressure (OP) of broodstock stocked in a salinity of 25-27\%o falls rapidly to a value close to the isosmotic point, the ion gradient with the external medium tending to be cancelled out. However, we have shown that a decrease in blood OP was associated with an increase in the affinity of the haemocyanin for oxygen (Wabete et al., in preparation). Thus the animals that were put into an isotonic medium did not develop the problems of ion exchange and respiratory physiology described in shrimp put in a hyperosmotic medium. This probably explains the improved survival rate of the animals kept in an 
isotonic medium after handling (Fig. 2E, 3C and 4B). In this study, we also demonstrated that survival rate in handled sub-adult animals could be improved twice if, as well as adjusting salinity to an isosmotic value, we also didn't feed animals and regulated the water at $26{ }^{\circ} \mathrm{C}$ (Fig. 2). Indeed, in an earlier study, we showed that in a stressed animal the speed of osmoregulatory capacity recovery was temperature-dependent and was accelerated in heated water (Wabete et al., 2004). Moreover, we know that when the shrimp takes food, there is an increase in the oxidative metabolism (Wabete et al., in preparation) and major changes in ionoregulation (Lignot et al., 1999). In the crab Carcinus maenas, when the metabolism and therefore $\mathrm{O}_{2}$ consumption are activated after a meal, the blood $\mathrm{pH}$ drops (Legeay et Massabuau, 1999; 2000). This postprandial acidosis leads to a decrease in the oxygen's affinity of the haemocyanin in order to favour the release of $\mathrm{O}_{2}$ into the tissues. The blood capacity to carry $\mathrm{O}_{2}$ is thus linked to a subtle adjustment of the respiratory pigment characteristics via blood $\mathrm{pH}$ and trans-gill ion exchanges between blood and water (Legeay et Massabuau, 1999). In the crayfish Astacus leptodactylus, this type of $\mathrm{pH}$ regulation would become impossible when mechanisms for maintaining the osmoregulatory capacity start working (Burtin and Massabuau, 1988).

The considerable improvement in survival rate (Fig. 2E) by transferring animals according to the LSD OT protocol (salinity close to the isosmotic point, animals unfed and optimal temperature) can thus be explained by a synergy of the three factors considered in this study. These three factors contribute to maintain the balance of the ion exchanges system in animals subjected to handling stress: (i) isotonic water, which blocks the ion imbalance; (ii) optimal temperature, which promotes ionoregulation and recovery of homeostasis, and (iii) no food which avoids stimulating the post-prandial metabolism and enhances acid-base regulation by trans-gill ion exchanges.

At the EDN hatchery, between 2001 and 2003, broodstock mortalities associated with handling stresses (transfer and eyestalk ablation in the females) were higher in summer (65.5\%) than in winter (33.5\%) (Fig. 8B). These mortality rates in summer are specific to the EDN hatchery, and we are unable, for the moment, to explain them in physiological terms. Nevertheless, they may be related to the conditions of high stocking density during the tranport that were applied by this hatchery (pers. com. H. Schneider, senior manager, EDN). However, as in winter, mortality rates decreased considerably when the animals were kept in "physiological comfort" during handling.

\section{Application of the LSD OT protocol on reproduction performances}

To ensure the reliability of post-larval production in hatcheries, it is important to understand the origins of variations in the reproduction of penaeid shrimps in captivity. The main studies in this area have focused on the influence of nutrition (Wouters et al., 2001), size or age (Peixoto et al., 2004), and season (Crocos et Coman, 1997) on the spawning performances. New Caledonia, which is located in the subtropical area, has two very distinct seasons. During the austral winter, water temperatures in ponds fall below $20-22{ }^{\circ} \mathrm{C}$ and can increase above $28-30{ }^{\circ} \mathrm{C}$ in summer. In the hot season, especially when temperatures are at their highest, the rate of nauplii production per female is considerably reduced (Tab. 1). This phenomenon has to be linked with the drop in males' fertility. Indeed, Pascual et al. (1998) have shown that the sperm quality of Penaeus setiferus declined with an increase of the spermatophores' necrosis number when the temperature rose over $28^{\circ} \mathrm{C}$. Crocos and Coman (1997) have shown a relationship between the rate of nauplii production and the season in wild broodstock, with minimum production in March (southern hemisphere summer). However, these authors also revealed a high level of interaction with age or size of the shrimp. 
The consequences of handling stress on broodstock shrimp (transfer and eyestalk ablation) have been less documented. A few authors (AQUACOP, 1979; Primavera, 1983; Browdy, 1998) have observed a relationship between the handling stress and broodstock mortality. However no study has been carried out, to our knowledge, on the consequences of this handling on reproduction. Our results on this subject are striking: when females are handled in conditions of "physiological comfort" (LSD OT), the latency period (time between eyestalk ablation and the first spawns) is significantly shortened and the acceleration phase (rapid increase in the percentage of daily spawning) is considerably longer (Fig. 6). Ovarian maturation occurs when the secondary vitellogenesis is completed: the biosynthesis of proteins and lipids, their transport and storage in the ovocytes (Charniaux-Cotton, 1985; Quackenbush, 2001) lead to an increase of 4 to 9 fold the ovarian weight in 3 to 7 days (Jeckel et al., 1989; Mourente and Rodriguez, 1991). The whole process involves a considerable mobilisation of energy over a short period for successful achievement. In the shrimp Palaemonetes pugio vitellogenesis is described as an increase in metabolic demand, associated with an increase in the heartbeat rate (Guadagnoli and Reiber, 2005). Secondary vitellogenesis can thus not be triggered if the female is under stress as the animal prioritizes its metabolic demand to its homeostasis recovery. Thus, animals that are transferred and handled in standard conditions would have to devote more time and energy to osmoregulation. This would therefore extend the latency period between eyestalk ablation and the first spawn.

Only a part of the females that begin the reproduction cycle will complete vitellogenesis and spawn, and some of them will have several vitellogenesis resulting in successive spawns (Beard and Wickins, 1980; Emmerson, 1980). For the shrimps transferred under "physiological comfort", the lengthening of the acceleration phase to reach a reproductive peak can be explained by a greater number of females that spawn (the LSD OT treatment multiplies survival of the females by 2.7, Fig. 5). Meanwhile, the shortening of the latency period under the LSD OT protocol, contributes to an increase in the number of spawns per female (Fig. 7).

In summer in the Saint-Vincent hatchery (Ifremer), we observed a greater number of nauplii produced per female in the control animals compared with LSD OT treatment (Tab. 1). This apparent counter-performance could be explained in standard transfer conditions, by a form of selection carried out on the most resistant broodstock which may also be the most fertile. After handling in conditions of "physiological comfort", some of the least fertile females that have survived will take part in reproduction leading to a drop in the average number of nauplii per spawn.

Nevertheless, transfer of the animals under "physiological comfort" produces considerable improvements in productivity in most of the production indicators (survival after transfer and eyestalk ablation, average number of spawns per female, and the total number of nauplii produced) (Tab. 1). These improvements have been estimated experimentally at $60 \%$ to $170 \%$ of extra nauplii in hot and cold seasons, respectively.

\section{Conclusion}

Handling broodstock under "physiological comfort" reduces the impact of stress thus

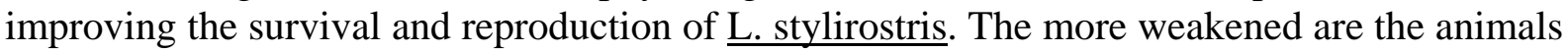
(season, pre-moult stage), the more significant are the improvements. The application of LSD OT protocol should considerably reduce production costs either by reducing the number of earthen ponds devoted to broodstock or by shortening the production cycle in the hatchery. This latest consequence would increase the time for implementing sanitary measures in the hatchery and thus reduce the risks of disease in larval production. The results of our studies are being successfully applied in commercial hatcheries in New Caledonia. The developed 


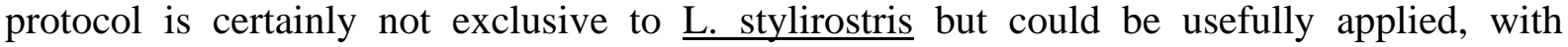
adjustments of temperature and salinity, to other broodstock shrimps such as Penaeus $\underline{\text { monodon and Litopenaeus vannamei. }}$

Acknowledgements: The authors thank Mr Christian GALINIE (Blue Lagoon Farm manager) and Mr Hervé SCHNEIDER (Ecloserie du Nord manager) for their kind support and all of the zootechnical staff of Saint-Vincent hatchery. 


\section{References}

AQUACOP, 1979. Penaeid reared Brood Stock : closing the cycle of $\underline{P}$. monodon, $\underline{P}$.

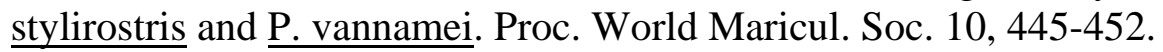

AQUACOP, 1983. Constitution of broodstock, maturation, spawning and hatching systems for penaeid shrimps in the Centre Océanologique du Pacifique. In: , Mc Vey, J.P. (Editor), Handbook of MaricultureCrustacean Aquaculture vol. 1. CRC Press, Boca Raton, FL, pp. 105-121.

Beard, T.W., Wickins, J.F., 1980. Breeding of Penaeus monodon Fabricius in laboratory recirculation systems. Aquaculture 20, 103-118.

Browdy, C.L., 1992. A review of the reproductive biology of Penaeus species: perspectives on controlled shrimp maturation systems for high quality nauplii production. J. Wyban, ed. Proceedings of the special session on shrimp farming, World Aquaculture Society, Baton Rouge, Louisiana, pp 25-51.

Browdy, C.L., 1998. Recent developments in penaeid broodstock and seed production technologies : improving the outlook for superior captive stocks. Aquaculture, 164, 3-21.

Burtin, B., Massabuau, J.-C., 1988. Switch from metabolic to ventilatory regulation of extracellular pH in crayfish. J. Exp. Biol. 137, 411-420.

Chamberlain, G.W., Lawrence, A.L., 1981. Effect of light intensity and male and female eyestalk ablation on reproduction of Penaeus stylirostris and Penaeus vannamei. J. World Maric. Soc. 12 (2), 357-372.

Charmantier-Daurez, M., Thuet, P., Charmantier, G., Trilles, J.-P., 1988. Tolérance à la salinité et osmorégulation chez les post-larves de Penaeus japonicus et $\underline{P \text {. chinensis. Effet }}$ de la température. Aquat. Living Resource 1, 267-276

Charniaux-Cotton, H., 1985. Vitellogenesis and its control in malacostracan Crustacea. American Zoologist 2, 197-206.

Crocos P.J., Coman, G.J., 1997. Seasonal and age variability in the reproductive performance of Penaeus semisulcatus broodstock: optimizing broodstock selection. Aquaculture 155, 55-67

Drach, P., Tchernigovtzeff, C., 1967. Sur la méthode de détermination des stades d'intermue et son application générale aux crustacés. Vie Milieu 18, 596-609.

Emmerson, W.D., 1980. Induced maturation of prawn Penaeus indicus. Marine Ecology and Progress Series 2, 121-131.

Forgue, J., Truchot, J.P., Massabuau, J.-C., 1992. Low arterial $\mathrm{PO}_{2}$ in resting crustaceans is independent of blood oxygen-affinity. J. Exp. Biol. 170: 257-264.

Galinié, C., 1989. Shrimp aquaculture in New Caledonia. Advances in tropical aquaculture Tahiti, Feb 20-March 4. AQUACOP IFREMER Actes de Colloque 9, 45-50.

Guadagnoli, J.A., Reiber, C.L., 2005. Changes in cardiac output and hemolymph flow during hypoxic exposure in the gravid grass shrimp, Palaemonetes pugio. J. Comp.Physiol. B. 175, 313-322.

Jeckel, W.H., Aizpun de Moreno, J.E., Moreno, V.J., 1989. Biochemical composition, lipid classes and fatty acids in the ovary of the shrimp Pleoticus muelleri Bate. Comp. Biochem. Physiol. 92B, 271-276.

Legeay, A., Massabuau, J.-C., 1999. Blood oxygen requirement in resting crab Carcinus maenas 24 hours after feeding. Canad. J. Zool. 77, 784-794.

Legeay, A., Massabuau, J.-C., 2000. Effect of water salinity on resistance to hypoxia in resting green crab Carcinus maenas after feeding. Marine Biol. 136, 387-396.

Lemaire, P., Bernard, E., Martinez-Paz, J.-A., Chim, L., 2002. Combined effects of temperature and salinity on osmoregulation of juvenile and sub-adult Penaeus stylirostris. Aquaculture 209, 307-317. 
Lignot J.-H., Cochard J.C., Soyez C., Lemaire P., Charmantier G., 1999. Osmoregulatory capacity according to nutritional status, molt stage and body weight in Penaeus stylirostris. Aquaculture 170, 79-92.

Massabuau, J.C., Forgue, J., 1996. A field versus laboratory study of blood oxygen status in normoxic crabs at different temperatures. Can J Zool. 74, 423-430.

Mourente, G., Rodriguez, A., 1991. Variation in the lipid content of wild-caught females of the marine shrimp Penaeus kerathurus during sexual maturation. Mar. Biol. 110, 21-28.

Ottogalli, L., Galinie, C., Goxe, D., 1988. Reproduction in captivity of Penaeus stylirostris in New Caledonia. J. Aquac. Trop. 3, 111-125.

Pascual, C., Valera, E., Re-Regis, C., Gaxiola, G., Sanchez, A., Ramos, L., Soto, L.A., Rosas C., 1998. Effect of temperature on reproductive tract condition of Penaeus setiferus adult males. J. World Aquaculture Soc. 29, 447-484.

Peixoto S., Cavammo, R.O., Wasielesky, W., D’Incao, F., Krummenauer, D., Milach, Â.M., 2004. Effects of age and size on reproductive performance of captive Farfantepenaeus paulensis broodstock. Aquaculture 238, 173-182.

Perazzolo, L.M., Gargioni, R., Ogliari, P., Barracco, M.A.A., 2002. Evaluation of some hemato-immunological parameters in the shrimp Farfentepenaeus paulensis submitted to environmental and physiological stress. Aquaculture 214, 19-33.

Pérez Farfante, I., Kensley, B., 1997. Penaeoid and Sergestoid Shrimps and Prawns of the World: Keys and Diagnoses for the Families and Genera. Mémoires du Muséum Nationale d'Histoire Naturelle, tome 175, 233p.

Primavera, H., 1983. Broodstock of Sugpo, Penaeus monodon Fabricius. Extension Manual $\mathrm{n}^{\circ} 7,3^{\text {rd }}$ ed. Southeast Asian Fisheries Development Center, Tigbauan, Philippines.

Quakenbush, L.S., 2001. Yolk synthesis in the marine shrimp, Penaeus vannamei. Amer. Zool. 41, 458-464.

Rosas, C., Fernandez, I., Brito, R., Diaz-Iglesia, E., 1993. The effect of eyestalk ablation on the energy balance of the pink shrimp, Penaeus notialis. Comp. Biochem. Physiol. 104A(1), 183-187.

Truchot, J.P., 1987. Comparative aspects of extracellular acid-base balance. Springer-Verlag. Berlin Heidelberg. 248p.

Wabete, N., Chim, L., Lemaire, P., Massabuau, J.-C., 2004. Caractérisation de problèmes de physiologie respiratoire et d'échanges ioniques associés à la manipulation chez la crevette pénéide Litopenaeus stylirostris à $20{ }^{\circ} \mathrm{C}$. Styli 2003. Trente ans de crevetticulture en Nouvelle-Calédonie. Ed. Ifremer. Actes Colloq. 38, 75-84.

Wouters, R., Lavens, P., Nieto, J., Sorgeloos, P., 2001. Penaeid shrimp broodstock nutrition: an updated review on research and development. Aquaculture 202, 1-21.

Wood, C.M., 1989. The physiological problems of fish in acid waters. Soc. For Exp. Biology Sem. Series 34, 125-151. 


\section{Tables}

Table 1: Summary of results obtained at the Saint-Vincent hatchery (Ifremer) according to season and transfer protocol. Estimate, on the basis of 100 broodstock shrimps, of the total number of nauplii harvested and improvements obtained by applying the new protocol.

\begin{tabular}{|c|c|c|c|}
\hline Season & Standard Protocol & LSD HT Protocol & Gain \\
\hline & $\underline{\text { Survival rate (\%) }} \underline{\underline{(1)}}$ & & \\
\hline Summer & 89,3 & 93,3 & $4 \%$ \\
\hline \multirow[t]{2}{*}{ Winter } & 70,5 & 89,1 & $26 \%$ \\
\hline & $\underline{\text { Spawning rate per female }}^{(2)}$ & & \\
\hline Summer & 0,6 & 1,15 & $92 \%$ \\
\hline \multirow[t]{2}{*}{ Winter } & 0,85 & 1,65 & $94 \%$ \\
\hline & Total spawning number & & \\
\hline Summer & 54 & 107 & $100 \%$ \\
\hline \multirow[t]{2}{*}{ Winter } & 60 & 147 & $145 \%$ \\
\hline & $\underline{\text { Nauplii number per female }}$ & & \\
\hline Summer & 81071 & 64938 & $-20 \%$ \\
\hline \multirow[t]{2}{*}{ Winter } & 120000 & 134302 & $12 \%$ \\
\hline & $\underline{\text { Total Nauplii number }}$ & & \\
\hline Summer & 4343807 & 6967469 & $60 \%$ \\
\hline Winter & 7191000 & 19744456 & $175 \%$ \\
\hline
\end{tabular}

Based on 100 females transfered in hatchery.

(1) 4 days after transfer.

(2) 10 and 17 days following eyestalk ablation in summer and winter respectively.

Table 2: Total number of nauplii produced for 100 females transferred into the hatchery "Ecloserie du Nord" in summer and winter according to transfer protocol applied.

\begin{tabular}{|c|c|c|c|c|c|c|c|}
\hline \multirow[t]{2}{*}{ Season } & \multicolumn{3}{|c|}{ Standard protocol } & \multicolumn{3}{|c|}{ LSD OT protocol } & \multirow[t]{2}{*}{ Gain } \\
\hline & $\mathrm{n}$ & Means & S.E. & $\mathrm{n}$ & Means & S.E. & \\
\hline Summer & 8 & 2149760 & 604312 & 4 & 3541297 & 605338 & $65 \%$ \\
\hline Winter & 6 & 7736925 & 1068434 & 3 & 8277597 & 3149718 & $7 \%$ \\
\hline
\end{tabular}




\section{Figures captions}

Figure 1: Haemolymph Osmolality as a function of the tank water osmolality ( $\mathrm{T}=26.7 \pm$

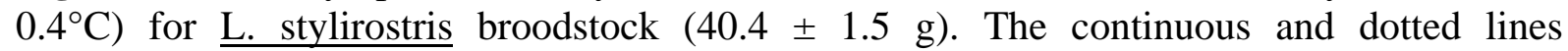
correspond to hyper then hypo-osmotic regulation (dashes: confidence interval at 95\%) and to the iso-osmolality line respectively. The intersection of the two gives the isosmotic point: 756 mosM.kg-1 (26.9\%o).

Figure 2: Mortality after transfer from outdoor pond into tanks in the hatchery according to treatment: A, $35 \%$ o, $21^{\circ} \mathrm{C}$, fed from the first day (Control); B, $26 \%$, $21^{\circ} \mathrm{C}$, fed; $\mathbf{C}, 26 \%$, $26^{\circ} \mathrm{C}$, fed; $\mathbf{D}, 26 \%$, $26^{\circ} \mathrm{C}$, unfed. E: cumulative survival rate after transfer according to treatment. Sub-adults (mean BW $=22.3 \pm 1.5 \mathrm{~g}$ ). Significant differences at $96 \mathrm{~h}(\mathrm{p}<0.01)$ among treatments after $\chi^{2}$ test are followed by different small letters

Figure 3: (A) Tank water salinity change, (B) haemolymph osmolality (PO, mean $\pm 1 \mathrm{ES}$; $\mathrm{n}=$ 6-8), and (C) mortality rate after transfer of the L. stylirostris broodstock (mean BW $=59.8 \pm$ $9.3 \mathrm{~g})$ into the hatchery under standard (-) and experimental LSD OT (--) conditions. (- - ) salinity of isotonic water. Reference blood osmolality determined for this species by Wabete et al. (in preparation).

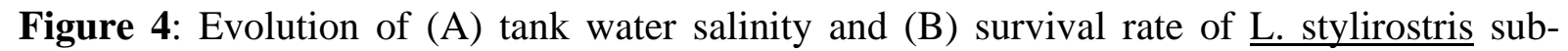
adults shrimps (mean BW $=24.1 \pm 2.5$ g) transferred into the hatchery under standard [35\%o; Temperature ambient; Fed] (-) and "Low Salt and Diet" [LSD: 26\%; Temperature ambient; Unfed] (---) conditions. The ambient temperature during experiment was $24.8 \pm 1.3^{\circ} \mathrm{C}$.

Figure 5: Evolution of broodstock survival rates (average $\pm 1 \mathrm{ES}$ ) after transfer into the hatchery. Influence of transfer conditions and Male - Female comparison. (*) Eyestalk ablation of the females $72 \mathrm{~h}$ after transfer.

Figure 6: Evolution of cumulative spawning (A \& B) and daily spawning rate (C \& D) in September 2003 and July 2004 in broodstock females of L. stylirostris transferred in standard conditions [35;20;F] and LSD OT conditions [26;26;UF]. $\left(^{\star}\right)$ Eyestalk ablation of the females.

Figure 7: Total number of spawns including relative proportions of different spawning ranks for each of the control tanks (STD $1 \& 2$ ) and experimental tanks (LSD OT 1\&2).

Figure 8: Average broodstock survival rate 4 (A) and 15 days (B) after their transfer into maturation tanks according to season and protocol applied. Average results from 23 productions (2001 to 2004) at the commercial hatchery, "Ecloserie du Nord”,. Summer : standard protocol, $\mathrm{n}=8$ and LSD OT protocol, $\mathrm{n}=4$; Winter : standard, $\mathrm{n}=6$; LSD OT, $\mathrm{n}=$ 3. $\left(^{*}\right)$ Result significantly different from that obtained in standard conditions $(p<0.05)$. 


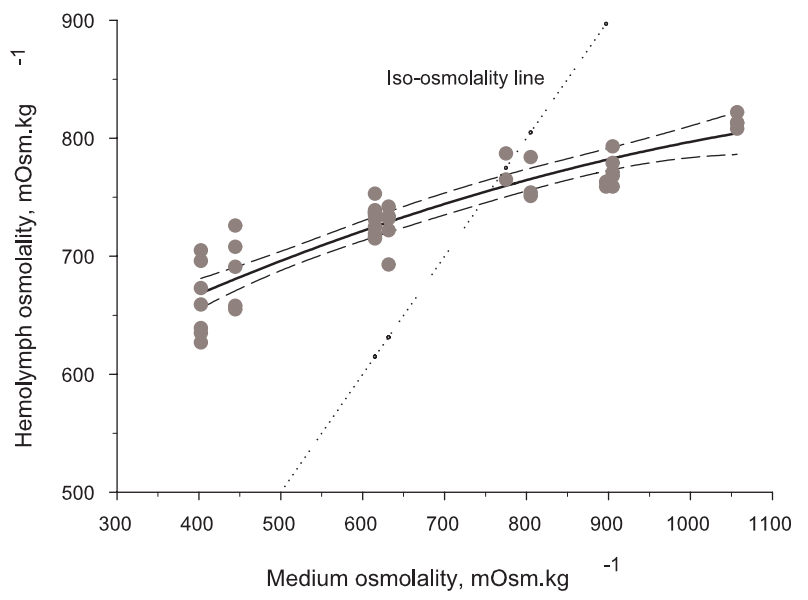

Figure 1 


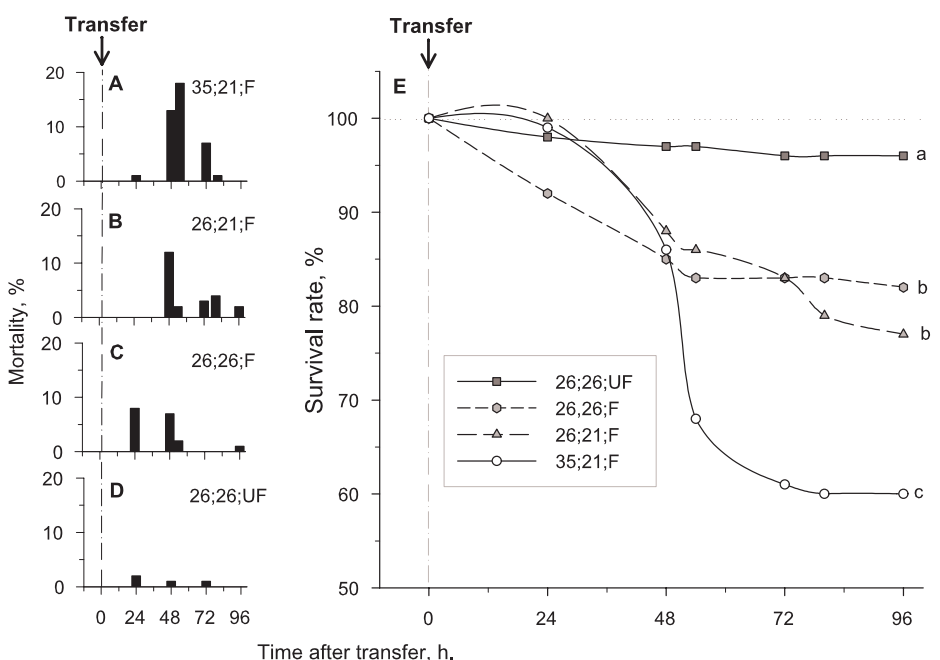

Figure 

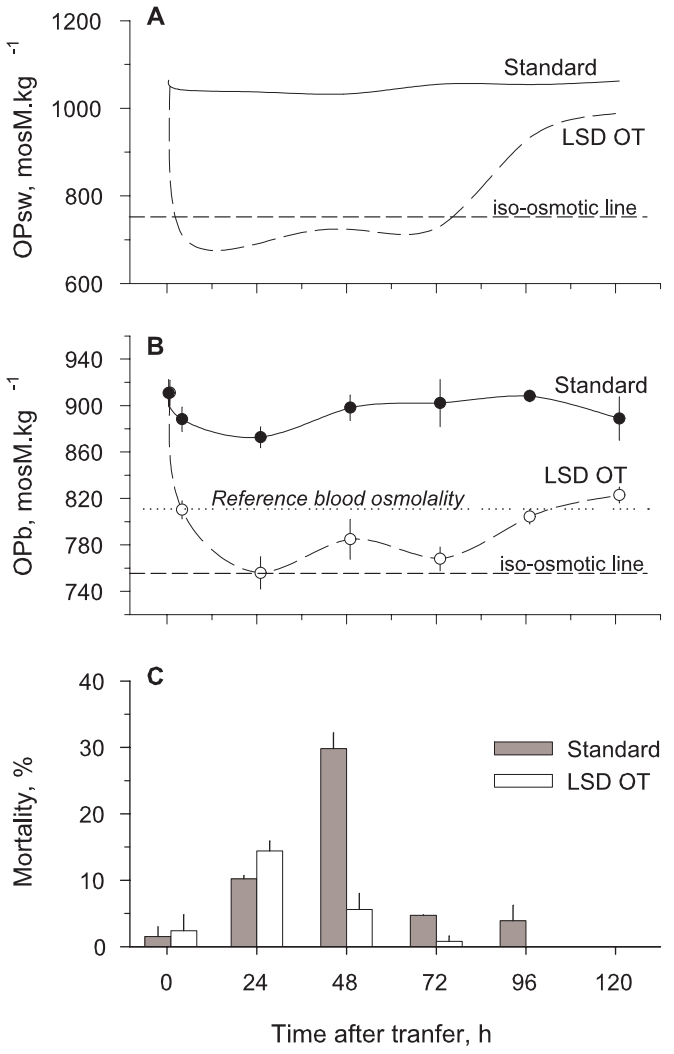

Figure 3 

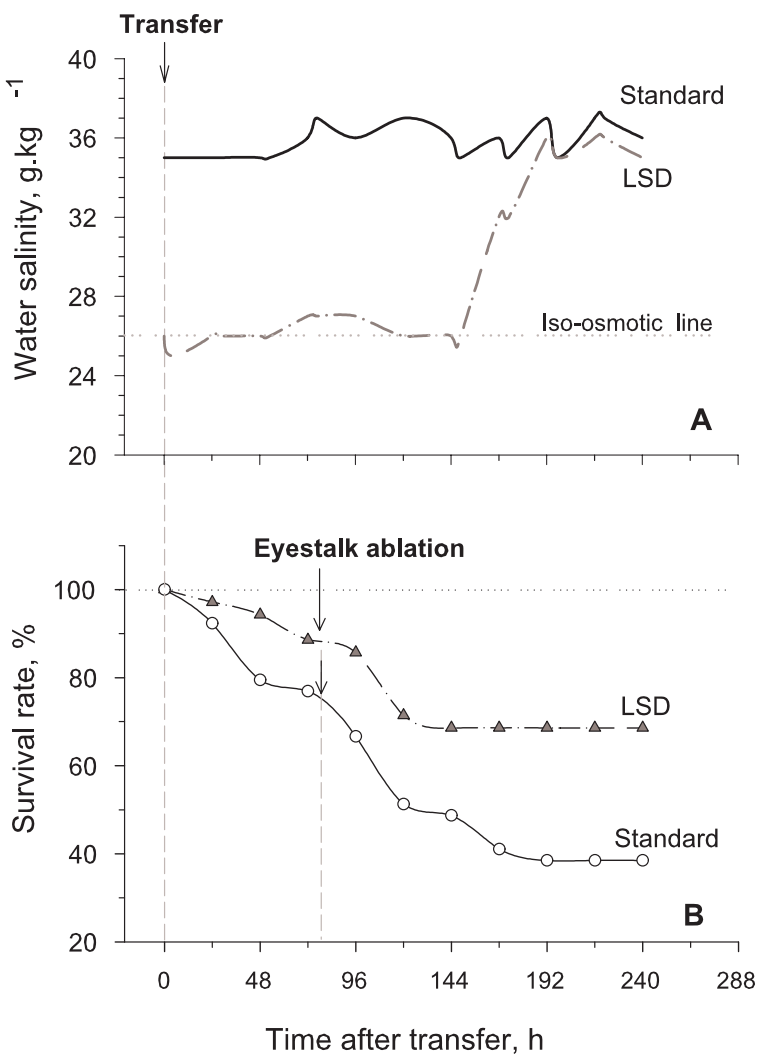

Figure 4 


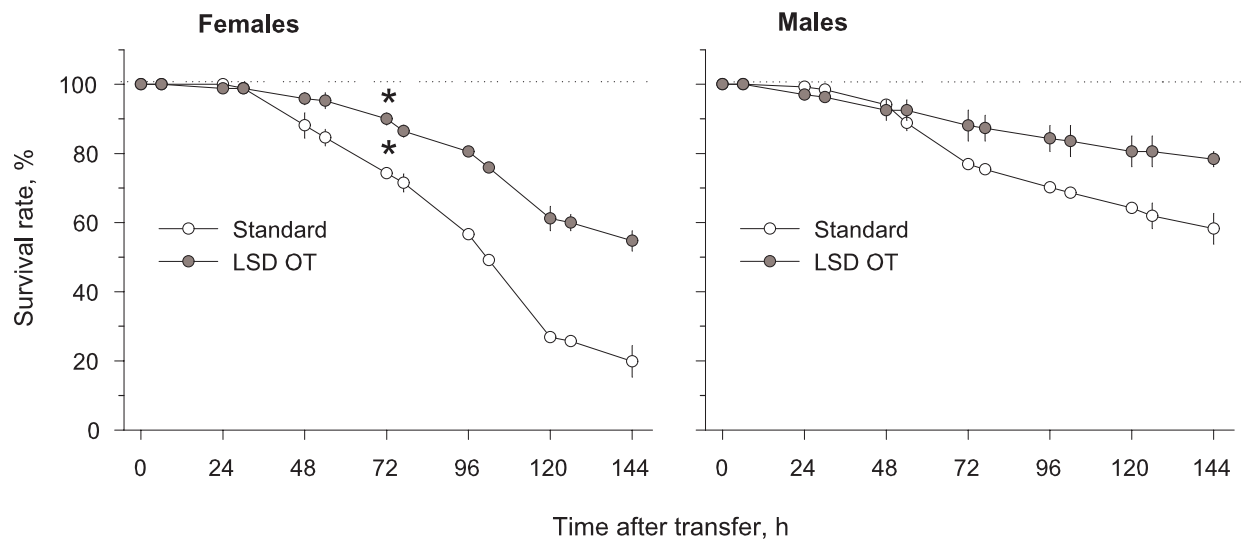

Figure 5 

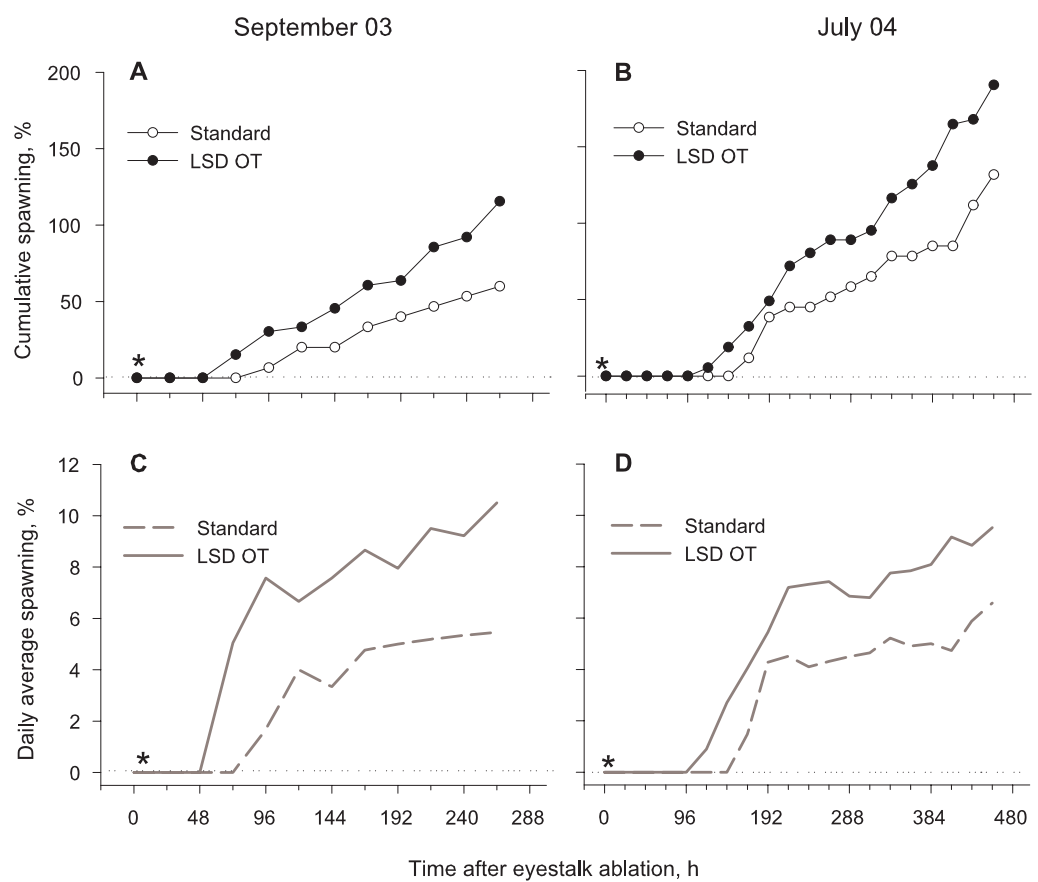

Figure 6 


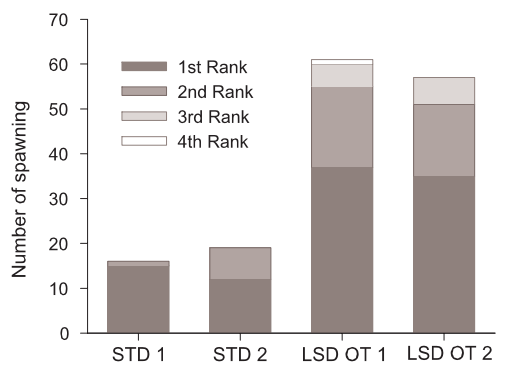

Figure 7 


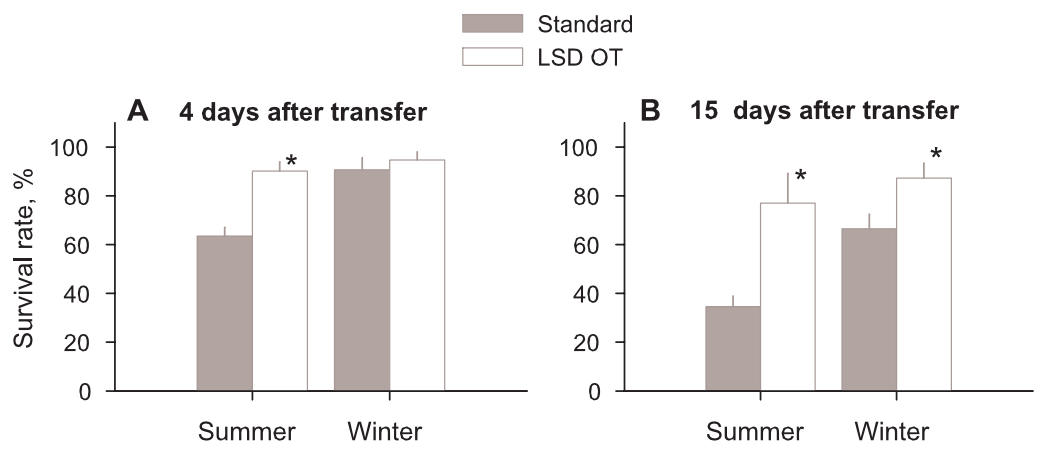

Figure 8 